\title{
The Qur'anic Approach to Development- Spiritual and Social
}

\author{
Bilal Ahmad Bhat \\ Ph.D Research Scholar, School of Education and Behavioral Sciences, University of Kashmir, \\ Kashmir, India
}

Email: bhatbilaln90@rediffmail.com

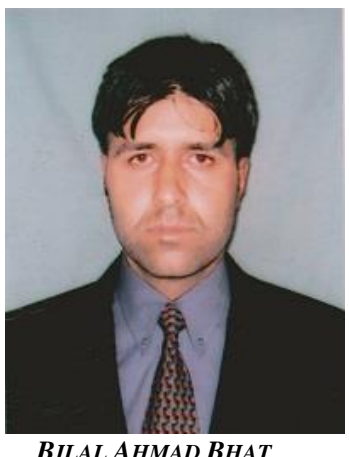

Keywords:

Qur'anic approach to spiritual development, Qur'anic approach to social development.

\begin{abstract}
A B S T R A C T
Qur'anic education is an essential need to change the status of human beings. The Qur'anic approach can play a very important role in the society for the development of human beings. The Qur'an, in the present times is the most important way for individuals to develop themselves spiritually and socially. Qur'an provides opportunity for everybody to sustain their level and pace of development.The purpose of this study is to find out the effect of the Qur'anic approach on spiritual and social development. For the all-round development of a Childs personality, Qur'anic approach plays a vital role. Qur'anic approach broadens the outlook of human beings. The followers of Islam accepted Qur'an as the medium of "Najat" because it is only through Qur'an that one is able to make a distinction between religious and non-religious and between good and bad. The aim of Qur'anic education is the inculcation of moral and spiritual values among students. Qur'anic education brings stability in the prevailing social system. The focus of Qur'anic education is to develop a particular type of morality based on Islamic doctrines and to expound Islamic laws and principles.
\end{abstract}

Citation: Bilal Ahmad Bhat (2019). The Qur'anic Approach to DevelopmentSpiritual and Social. International Journal of Advanced Multidisciplinary Scientific Research (IJAMSR) ISSN:2581-4281, 2 (1), January, 2019, \# Art.1123, pp 87-91

\section{Introduction}

The Qur'an is a complete code of life and encompasses all dimensions of human life. Teachings of Qur'an ensure all-round development not only for the Muslims, but also for the whole world. The basic concern of social-spiritual development in the Qur'an is only for human welfare. A Qur'anic approach to spiritual and social development is absolutely holy. Qur'an considers man as a social agent and this very concept is the center of the development process in all human beings. Social 
and spiritual development is interrelated to one another. Qur'an has started its journey to maintain stability in the world. Qur'an stood for the basic and fundamental rights of each and every human being. The Qur'an has shown a very clear and reliable way of building a developmental world for the welfare of our society. The ethical ideal of Qur'an is to maintain the harmony between religion and life thus can satisfy both the spiritual and the worldly desire of man (Rahman, 1956:52)". Brotherhood as per Qur'an is a universal and undisputed fact. The Qur'an has promoted the idea of brotherhood among the people in order to reduce the social inequalities in society.

\section{Qur'anic Approach to Spiritual Development}

Spiritual development is the development of personality towards a religious or spiritual desired better personality. The important aim of Qur'anic education is the inculcation of moral and spiritual values among students. The beginning of Islam is realization. The actual target of Islam is spiritual progress. In the Qur'an, Islam's actual goal is purification and cleansing. Qur'an helps to develop higher awareness or to develop higher consciousness.Through Qur'anic education, we are becoming more conscious and aware of our inner being. With the help of Qur'anic education, we are able to uncover the inner spirit that is always present, but hidden beyond the ego personality. Spiritual development is of great importance for everyone. Qur'an provides the basis for a better and a more harmonious life, a life free of fear and anxiety. The Qur'anic approach helps to develop inner power and strength which are very useful and important tools. Qur'anic approach is a method of growing and becoming a stronger, happier, and a more responsible person. Qur'an makes us understand that a balanced life requires not only the necessities of the body, but also of the spirit, and this is the role of spiritual development. Qur'an helps to develop tolerance, patience, tact and consideration for others. Through Qur'anic approach we are awakening our soul through meditation and feel the energetic vibrations within. Qur'an has proved that when we grow spiritually, our perception changes and the way we see the world around us has also changed. Through Qur'anic approach spiritual growth and development brings about a positive change in our life. Not only as we become optimistic and positive in life, but also become calmer and peaceful. Anger and other negative emotions take a back seat and we start feeling happy and comfortable in any circumstances.

With the help of the Qur'an, we are able to solve all problems which exist in our day to day life. Following Qur'anic path helps you to see the world with a new pair of glasses. As we develop ourselves spiritually, pride, jealousy, selfishness starts to melt away. We are becoming humble, generous and non-violent. When we are spiritually inclined, we can keep stress at bay and spread the message of love and peace around. Qur'an appeals us to value our relationships. People who are spiritually inclined, lead a balanced lifestyle. Prayers play an important part in spiritual growth and development. Qur'anic education develops strength, courage and inner peace. The Qur'anic approach can help to make human beings better citizens. The spiritual aim of Qur'anic education saves the individual as well as 


\section{International Journal of Advanced Multidisciplinary Scientific Research (IJAMSR) ISSN:2581-4281}

I J A M S R

the society from disaster, destruction, exploitation, selfishness, aggression and hatred. Qur'anic education enables the individual to lead a whole, peaceful and happy life. Qur'anic education fosters love, kindness, sympathy, compassion and affection, which strengthen human relationships. Qur'an helps the individual to shun evil, corruption and greed. Qur'anic education makes the students religious minded, honest and noble. Betterment of the world depends upon spiritual development. Qur'anic education will raise man to a high level by making him a man of character, honesty and integrity. It will make him gentle, pious, cooperative, humble, broad minded, tolerant, enlightened, and progressive and peace loving. The Qur'an provides the basis of true humanitarianism. It encourages the policy of 'live and let live' and love for humanity.

\section{Qur'anic Approach to Social Development}

The aim of Qur'anic education is to prepare the individual for successful participation in activities. Qur'an believes that the individual should be secured to promote the welfare of the society. The aim of Qur'anic education is to make the individual socially sufficient. Qur'anic education makes a man physically strong, intellectually enlightened, culturally refined, vocationally self sufficient, and morally well disciplined. Qur'an helps an individual to control his environment and fulfill his possibilities. All Qur'anic education proceeds by the participation of the individual in the social consciousness of the race. Qur'anic way to social efficiency becomes the measure of man's success in life.
Through Qur'anic approach an individual willingly sacrifices his own desires in order to contribute to social progress. Qur'anic education gives top priority to the welfare of the society. Qur'anic education makes an individual cultured and civilized. Qualities like sympathy, social service, obedience, kindness, love and brotherhood are developed through Qur'anic approach. Qur'anic teachings provides peace, justice and security. Qur'anic education advocates working for the welfare and prosperity of our society.

Social development is a vital issue in the contemporary world. It has a religious appeal in the Qur'an. The Qur'an is a complete and comprehensive code of life. It gives equal importance to material as well as spiritual life. This is a humble endeavor to prove that the Qur'an is not antithetical to desired social-spiritual development. It will try to explore the theoretical foundations for social development of a country. Actually, Qur'an exalts reason and freedom, encourages progress, and prohibits all deeds that are against to the overall development of human society. Qur'an ensures social justice and highly advocates many ideas that are intimately related to the development of human beings and human society. Without realizing the true teachings of the Qur'an no one can be able to feel the real appeal of Qur'anic prescriptions for the development of a society. Qur'anic approach is a total and comprehensive way of life. Qur'an fully recognizes both material and spiritual needs of man and maintains social harmony through the implication of various social just orders. The Holy Qur'an very intimately relates to the benefit of 


\section{International Journal of Advanced Multidisciplinary Scientific Research (IJAMSR) ISSN:2581-4281}

a guild. Social development in Qur'an covers some important areas that are the basis for the socioeconomic development of a country. Social justice, social security, social insurance, zakat, charity, brotherhood, mutual respect, education are some areas of Qur'anic approach for explaining social system.

Qur'an, a way of peace, teaches universal love, mutual respect and brotherhood, preaches sympathy for others, encourages the utmost self-restraint and motivates man to abstain from violence and hatred. Qur'an is not only the combination of various laws but primarily it wants to civilize human beings through the attainment of self purification and through the formation of good character so that they would willingly submit to the law not only because of any surrounding fear of the government but because of their own moral initiatives from within. The concept of social development is one of the Islamic principal values that are inculcated in the Holy Qur'an. The correct action, whatever it be political, religious, social or economical, it is considered to be 'Ibadat' or the service of Almighty Allah. In this regard there is a very important verse in the Holy Qur'an, "It is not righteousness that you turn your face towards east or west, but it is righteousness to believe in Allah, and the last day, and the angels, and the books and the messengers; to spend of your substance, out of love for Him, for your kin, for orphans, for the needy, for the wayfarer, for those who ask, and for the ransom of the slaves, to be steadfast in prayer, and practice regular charity, to fulfill the contracts which we have made, and to be firm and patient, in pain and adversity, and throughout all periods of panic. Such are the people of truth, God-fearing" (Qur'an, 2:177). This verse is very philosophical and clearly shows that social welfare is a basic Islamic value, which is not less important than five times daily prayers. All the resources and the creations of the universe represent the unity of Almighty Allah. Therefore, preserving the universe, developing its resources and protecting social orders are the part of religion. Qur'an advocates some inevitable components that are the basis for social harmony and peace.

\section{CONCLUSION}

In conclusion, the paper strongly suggests the socialspiritual development process is fully compatible with the Qur'anic principles as the key for all round development. All the discussed aspects of socialspiritual field in the Qur'an are part of worship whereby people can get nearer to Allah. It is to be remembered that through Qur'anic education, Muslims are able to achieve proper development. The most important values that lead to remarkable developments in accordance with Qur'an are namely, respecting and honoring humans, maintaining economic balance, and developing plans for the longest amount of time possible. Qur'anic Education is a basic need of all human beings. Without Qur'anic education no nation can prosper in their personal, social, national and international life. Qur'an as the modern and civilizing force of the world offers a solution of the most unsolved problems which confront mankind today. Every holy book of the world encourages the life of honest living, but the Qur'an emphasizes most of the 
right livelihood and guarantees the rights of the workers and peasants. Human being dignity is tied up with his work and any sort of physical work is highly respected in the Qur'an. Qur'an teaches that workers should be treated with equality and kindness.

\section{References}

1) Ali, Maulana Muhammad. (1973). The Religion of Islam, Lahore, Pakistan, The Ahmadia AnjumanIsha'at Islam.

2) Amara, Muhammad. (1996). Islam and Human Rights: Requisite Necessities rather than Mere Rights, Rabat, Morocco,Translated by Mimoun Mokhtari, Publications of the Islamic Educational, Scientific and Cultural Organization.

3) Hai, Mohammad Abdul. (1983). Teachings of Islam, Delhi, India, Muktaba Alhasnat.

4) Hamidullah, Muhammad. (1992). Introduction to Islam, New Delhi, India, Kitab Bhavan.

5) Hasan, Sayed Mahmudul. (1962). Islam, Dacca, Islamic Foundation Bangladesh.

6) The Holy Qur'an, 2:188.

7) Ali, A. Y. (1978), The Holy Qur'an: Text, Translation and Commentary, Leicester, The Islamic Foundation. Al-Mawardi, A.M. (1955) AdabudDunya wad Din, Beirut, Darul-Fikr. AlQardawi (no date) Ar-Rasul wal'Ilmu.

8) Qur'an, Translated by: Naser Makarem Shirazi, Qom, Dar al Quaran Alkarim and History and Islamic Studies Office, First Edition, 1994.

9) Ibn Fares, Ahmed, Abd Al- salam Mohammad Haroon, Egypt, Mostafa AlbabiAlhalabi and Sons Pub.

10) Esfahani, Ragheb, “ Almofradat Fi Gharib Al Qur'an”, Tehran, BozarjomehrMostafavi Library, Heidari Printing office. 